\title{
EPSL
}

Earth and Planetary Science Letters 148 (1997) 287-298

\section{Dating of alteration episodes related to mercury mineralization in the Almadén district, Spain}

\author{
Cris M. Hall ${ }^{\text {a, * }}$, Pablo L. Higueras ${ }^{b}$, Stephen E. Kesler ${ }^{\text {a }}$, Rosario Lunar ${ }^{\mathrm{c}}$, \\ Hailing Dong ${ }^{a}$, Alex N. Halliday ${ }^{a}$ \\ a Deparment of Geological Sciences, University of Michigan. Ann Arbor, MJ 48109-1063, USA \\ ' Departamento de Ingeniería Geológica y Minera, Universidad de Castilla-La Mancha, 13400 Aimadér. Spain \\ c Departamento de Cristalografia y Mineralogía, Facultad de Geología, Universidad Complutense de Madrid, 28040 Madrid. Spain
}

Received 10 January 1996; revised 14 January 1997; accepted 4 February 1997

\begin{abstract}
The Almadén mercury deposits represent one of the largest geochemical anomalies on Earth, but the mode and timing of their formation remains a matter of controversy. There are two main possibilities: hydrothermal solutions associated with alkali basalt volcanism in the Silurian and Devonian; or regional hydrothermal activity during later Hercynian metamorphism. Although these models can be distinguished by determining the age of ore deposition, no suitable isotopic method had been applied to the problem prior to this study. We report here on vacuum encapsulated and more traditional laser ${ }^{40} \mathrm{Ar} /{ }^{39} \mathrm{Ar}$ dating performed on illite concentrates and $\mathrm{Cr}$-rich micas that are intimately associated with mercury mineralization in both Devonian and Silurian host rocks. Illite is associated with a later stage of $\mathrm{Hg}$ mineralization (cinnabar + kaolinite + pyrophyllite + chlorite) which locally replaces an earlier episode associated with carbonates and $\mathrm{Cr}$-mica. The dating results from illite separates suggest that the later stages of $\mathrm{Hg}$ mineralization or remobilization occurred about 360 $\mathrm{Ma}$, which is about $20 \mathrm{Ma}$ younger than any mercury-hosting rocks in the district and coincides with the onset of regional deformation during the Hercynian orogeny. $\mathrm{Cr}$-mica ages are variable and range from $365 \mathrm{Ma}$ to $427 \mathrm{Ma}$. This age range spans the period between the deposition of the Criadcro quartzite (the oldest sedimentary unit hosting mercury), and the later episode of mineralization. This suggests that mineralization started at least by the mid to lower Silurian and the younger argon ages for $\mathrm{Cr}$-mica could represent partial to nearly total argon loss, caused by the Hercynian metamorphic event. It appears that both postulated styles of mercury mineralization occurred, separated in time by up to 80 million years.
\end{abstract}

Key'rords: Almaden Spain; absolute age; alteration; mercury ores; mineralization

\section{Introduction}

Mercury deposits at Almadén contain over 30\% of world mercury reserves [1] in an area of only 500 $\mathrm{km}^{2}$, making them possibly the largest geochemical

\footnotetext{
${ }^{*}$ Corresponding author. Fax: +1 313763 4690. E-mail: cmhall@umich.edu
}

anomaly on the planet (Fig. 1). Although there are many large mineral deposits in the world, none contain the disproportionate amount of total global endowment seen at Almadén. Despite its immense size, there is uncertainty about how the mercury concentration formed. Mercury-forming hydrothermal solutions might have been associated with alkali basalt volcanism, which is part of the Silurian-De- 
vonian sequence, or it might have been emplaced (or remobilized) during later Hercynian deformation, metamorphism and granitic magmatism. Present models for global mercury budgets do not recognize submarine volcanism, hot spring activity, and metamorphism as major sources [2,3], making a test of these hypotheses important to studies of global mercury dispersion.

Knowledge of the age of mineralization at Almadén is necessary to resolve the controversy over the origin of this geochemical anomaly. If the 'volcanic model' is correct, the mercury deposits should be nearly the same age as their enclosing rocks. If the 'metamorphic-magmatic model' is correct, the deposits should be significantly younger than their enclosing rocks. Although the mercury deposits at Almadén are associated with hydrothermally altered rocks, the alteration minerals are generally regarded as being too fine grained for conventional age measurements. These minerals are amenable, however, to the recently developed vacuum encapsulated laser ${ }^{40} \mathrm{Ar} /{ }^{39} \mathrm{Ar}$ method for dating fine-grained micas $[4,5]$.

\section{Geologic setting of mercury mineralization at Almadén}

Mercury mineralization at Almadén is hosted by Paleozoic sedimentary and mafic volcanic rocks that unconformably overlie Pre-Ordovician basement rock in the central part of the Iberian Peninsula (Figs. 1 and 2). The Paleozoic sedimentary-volcanic package, which ranges from Ordovician to Devonian in age, consists of four transgressive sequences of shales and sandstones/quartzites, with mafic volcanic interlayers. The mafic volcanic rocks, which are largely alkali basalt [6-8], are found throughout the Silurian-Devonian part of the section and include dikes, sills, flows, and bedded pyroclastic deposits, including breccias known as frailesca that are well developed at most of the mercury mines. This sequence was folded, metamorphosed [9] and intruded locally by felsic plutonic rocks during Hercynian deformation, which ended in this area by the Pennsylvanian (Stephanian B-C) [10,11].

Mercury deposits at Almadén have been divided into two groups based on their host rocks $[1,12,13]$.

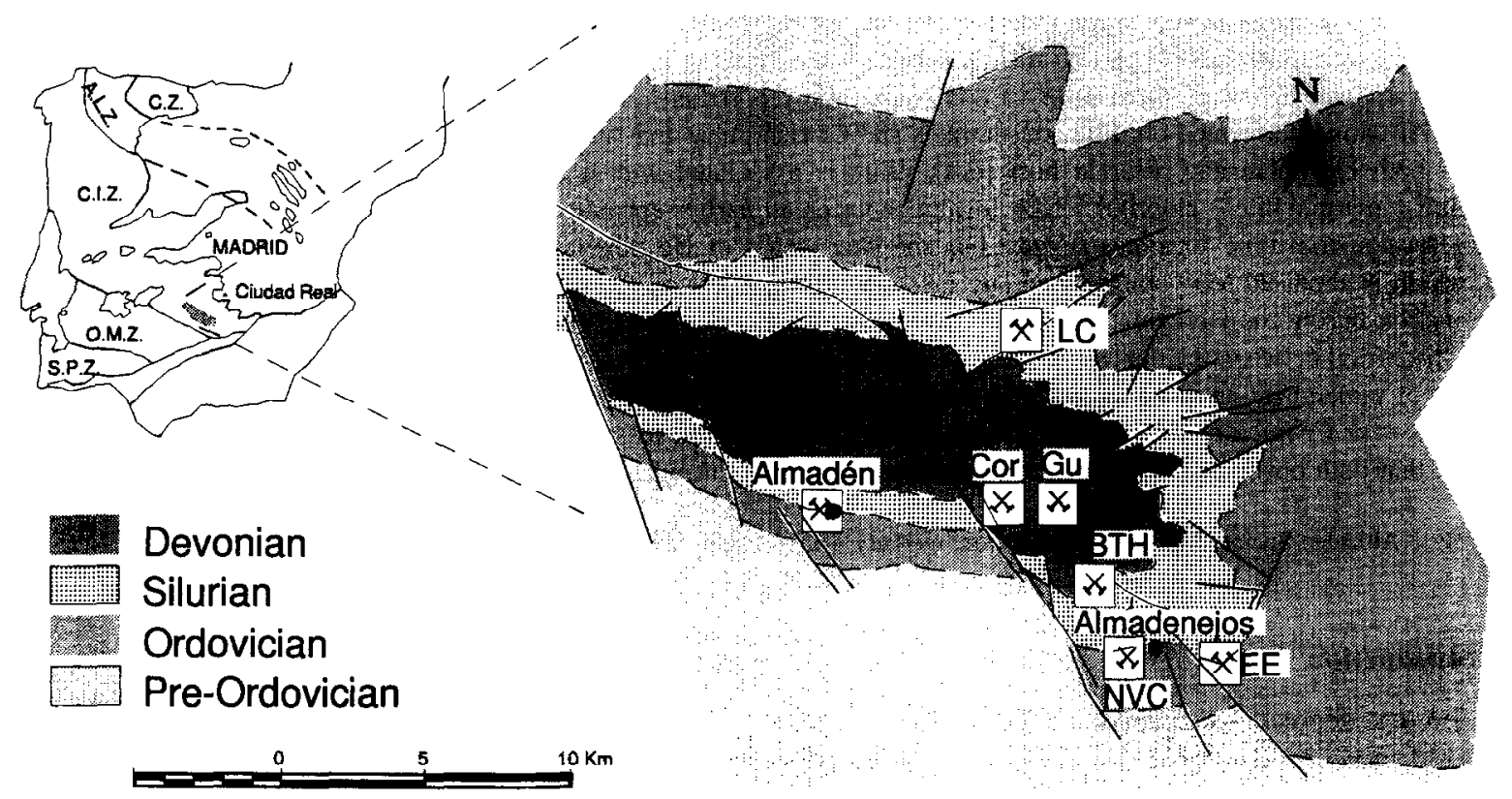

Fig. 1. Geologic map of the Almadén area in the central part of the Iberian peninsula showing location of the major deposits (after [13,26]). Key: $E E=$ El Entredicho; $L C=$ Las Cuevas; $G u=$ Guadalperal; $B T H=$ Burcio-Tres Hermanas; Cor $=$ Corchuelo; $N V C=$ Nueva and Vieja Concepción; C.Z = Cantabrian Zone; A.L.Z. = West Asturian-Leonian Zone; O.M.Z. = Ossa-Morena Zone; C.I.Z. = Central Iberian Zone; S.P.Z. = South Portuguese Zone. 

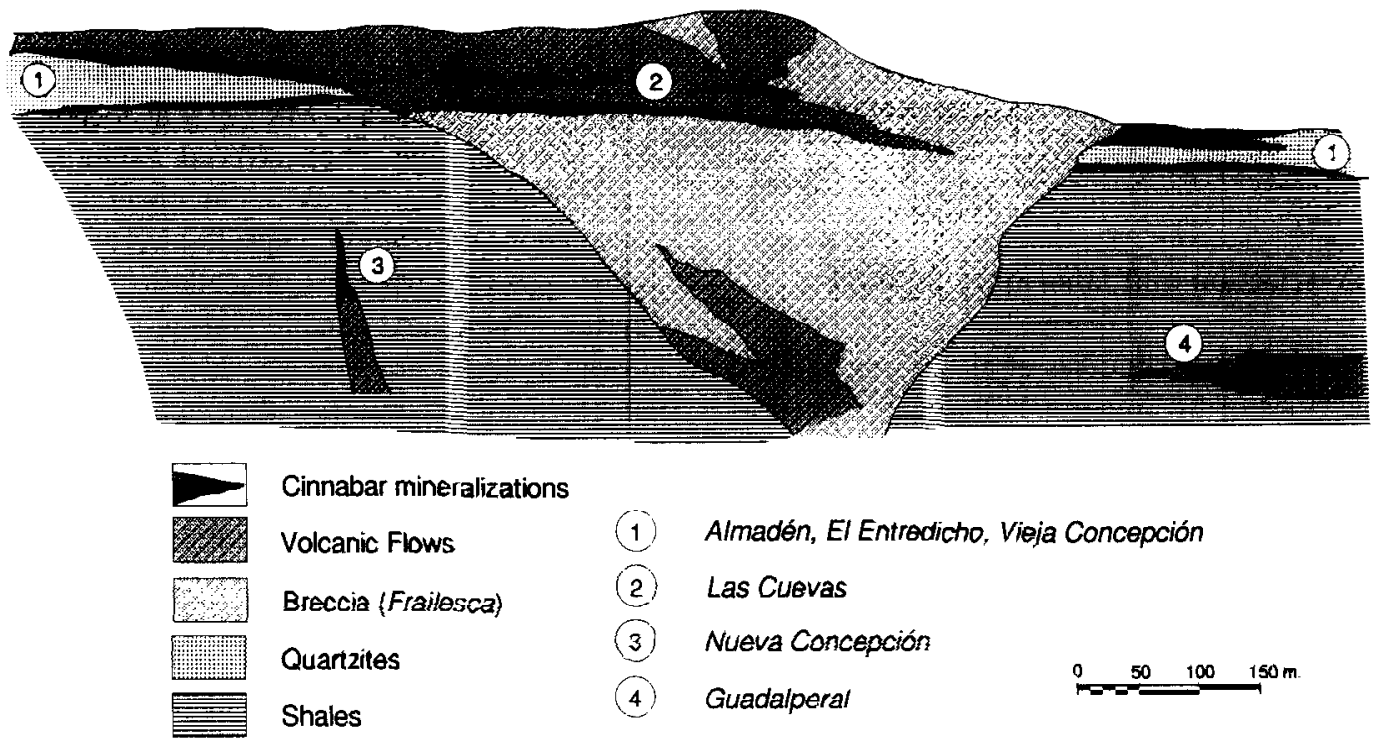

Fig. 2. Schematic illustration of styles of mercury mineralization in the Almadén district. Note that sediment-hosted deposits are found largely filling original porosity in quartzite and volcanic-hosted deposits are found largely in faults and other secondary porosity in both flows and breccias (modified from [7,34]). Las Cuevas deposits shown with hosting rocks unfolded to original horizontal orientation.

Best known are deposits hosted by sedimentary rocks, which are also the largest. These include the original Almadén deposit, as well as the large El Entredicho and smaller Vjeja Concepcion deposits, all of which are in the Lower Silurian Criadero quartzite (Rhuddanian to Lower Acronian [14]), and the El Burcio deposit, which is in the Devonian base quartzite. In most of these deposits, cinnabar is hosted largely by sedimentary rocks, where it fills original porosity, although some ore is also found in fractures in volcanic rock and/or frailesca-type breccia (Fig. 2). The other type of deposit is hosted largely by volcanic rocks and breccias, where it fills fractures. Deposits in this group include the large Las Cuevas and possibly the smaller El Nuevo Entredicho and La Nueva Concepciòn deposits (in Silurian rocks), as well as the Corchuelo and Guadelperal showings (in Devonian rocks).

The most widely held model for formation of the Almadén mercury deposits involves the alkali basalt volcanic rocks, which are restricted largely to the Almadén area [18]. Most deposits are closely related to frailesca-type breccias that formed during this volcanism, and some ore bodies even decrease in grade outward from the breccias $[12,13,15-17]$. The mercury itself might have been derived from the surrounding sediments [17], although a more likely source is the mafic volcanic rocks themselves [18]. Although some ore might have been deposited by exhalation of mercury-bearing solutions onto the seafloor $[12,17]$, most ore was probably deposited from shallow, subsurface hydrothermal systems circulating in the extensive sedimentary and volcanic/frailesca porosity. A second possible origin for the mercury mineralization involves the Hercynian metamorphism and magmatic activity that affected the sedimentary-volcanic sequence. Abundant mineralization, particularly at Las Cuevas [16], is hosted by fracture and other secondary porosity, which could have formed at this time by large-scale hydrothermal systems circulating through sedimentary and breccia porosity.

The rwo contrasting models for mercury mineralization would produce different geochronologic histories. Mineralization related to alkali basalt volcanism could have formed at several different times over the interval from the Upper Silurian to Devonian, whereas mineralization related to Hercynian metamorphism or intrusive activity would have been a single event that took place in the Pennsylvanian. Because the two types of mineralization formed different alteration assemblages it is possible to test 
their ages using isotopic age measurements. In this study, we have used ${ }^{40} \mathrm{Ar}-{ }^{39} \mathrm{Ar}$ methods to date fine-grained micas from the two assemblages, as described below.

\section{Sample selection and laboratory methods}

Higueras [19] and Higueras et al. [20] recognized two main types of hydrothermal alteration related to mercury mineralization in the Almadén area. The earliest of these, which consists of chlorite, $\mathrm{Cr}$-mica (fuchsite or mariposite?), and $\mathrm{Ca}-\mathrm{Mg}-\mathrm{Fe}$ carbonates, is best developed near stratiform mercury mineralization at Almadén and El Entredicho. This alteration is overprinted locally by various combinations of muscovite/illite, kaolinite and pyrophyllite, which are found around all types of mercury deposits, although they are best developed around fracturehosted ore. Higueras et al. [20] have shown that this second stage of alteration surrounds cinnabar-native mercury veins at Las Cuevas, where it changes outward from an inner pyrophyllite-kaolinite zone, through an illite-rich zone, into an outer chlorite-rich zone. In this study we have used Cr-mica from the earlier alteration assemblage at $\mathrm{El}$ Entredicho and fine-grained muscovite/illite from ore-related alteration in volcanic rocks at both the El Entredicho and the Las Cuevas deposits. Since the alteration products are hosted by volcanic rocks and not sedimentary rocks the problem of detrital contamination of the illites is avoided.

In the first part of this study, illite alteration from the second stage of mercury mineralization was analyzed. Altered rocks containing fine-grained muscovite/illite were crushed and milled by hand in an agate mill to $50 \mu \mathrm{m}$. The resulting powder underwent gravitational settling in distilled water at room temperature in a 11 graduated cylinder. After $8 \mathrm{~h}$ of repose, the top $10 \mathrm{~cm}$ of water was removed with the $<2 \mu \mathrm{m}$ fraction, which was used for analysis. One sample that was rich in calcite (SC-87/403, Table 1) was leached prior to settling with cold, dilute $\mathrm{HCl}$. The ${ }^{10} \mathrm{Ar}-{ }^{39} \mathrm{Ar}$ analyses were performed using the vacuum encapsulation technique outlined in Dong et al. [5]. A single clump of clay concentrate (approximately $1 \mathrm{~mm}$ ) was placed in a quartz vial that was then evacuated to a pressure of about $5 \times 10^{-8}$ torr. These quartz capsules were irradiated, along with packets of inter-laboratory standard hornblende Mmhb-1 (age $=520.4 \mathrm{Ma}$, [21]) at location L67 for $60 \mathrm{MWh}$ in the Phoenix-Ford Memorial nuclear reactor of the University of Michigan. After neutron irradiation, the sample capsules were loaded into a glass manifold which is attached to the laser fusion system. The quartz sample vials are equipped with a 'swan's neck' break-seal, which permits the measurement of Ar isotopes that are released from the sample during irradiation. Special care was taken to ensure that the clay samples remained cool during the encapsulation and irradiation procedures $\left(\mathrm{T}<50^{\circ} \mathrm{C}\right)$. There was no evidence for significant release of radiogenic ${ }^{40} \mathrm{Ar}$ during irradiation.

In the second part of the study, Cr-mica samples from the earliest stage of mercury mineralization were collected from mantle xenoliths in three samples from the El Entredicho mine. Sample EE-11 is an altered lapilli tuff (frailesca-type), with sedimentary and magmatic clasts. Magmatic clasts are ultramafic fragments and include textural relicts of olivine and pyroxene, with partly unaltered spinel vermicules. The Cr-mica occurs in pyroxene pseudomorphs, intimately intergrown with carbonate. Sample EE-12 is a basaltic lava flow with two large ultramafic xenoliths. In one of them, the Cr-mica is conspicuous in the pyroxene pseudomorphs, and is also intimately intergrown with carbonate. Sample EE-14, like EE-11, is a frailesca, without sedimentary clasts. Cr-mica is in a $1 \mathrm{~cm}$ diameter ultramafic clast. On one side of the clast the mica is distinctively green, but in the other side it trends toward being colorless (muscovite?). See Table 2 for electron microprobe analyses of mica from the three samples. In the case of the Cr-mica samples, small pieces (approximately $1 \mathrm{~mm}$ in diameter) of carbonate-hosted mica were irradiated for ${ }^{40} \mathrm{Ar} /{ }^{39} \mathrm{Ar}$ analysis, with no mineral separation being performed. Two chunks of EE-11 and one each of EE-12 and EE-14 were irradiated in evacuated quartz ampoules, and several pieces of each sample were irradiated in our standard packaging system which is evacuated but does not collect recoil gas. Unfortunately, the EE-14 capsule broke in the laboratory; however, we have data from three vacuum encapsulation runs (EE-11 and EE-12) and 9 more traditional laser step-heating analyses (all three samples). 
Table 1

Illite dating results

\begin{tabular}{|c|c|c|c|c|c|}
\hline Sample number & Deposit & Mineral assemblage & $\begin{array}{l}{ }^{39} \mathrm{Ar} \\
\text { in recoil } \\
\text { fraction } \\
(\%)\end{array}$ & $\begin{array}{l}\text { Total } \\
\text { gas } \\
\text { age } \\
\text { (Ma) }\end{array}$ & $\begin{array}{l}\text { Retention age } \\
\text { (Ma) }\end{array}$ \\
\hline $\mathrm{sc} 87 / 403$ & Las Cuevas & $\begin{array}{l}\text { muscovite /illite (40), chlorite }(40) \text {, } \\
\text { quartz }(10) \text {, plagioclase (10) }\end{array}$ & 12.7 & $320.9 \pm 1.2$ & $363.2 \pm .8$ \\
\hline ee 4 & El Entredicho & $\begin{array}{l}\text { muscovite /illite ( } 30) \text {, chlorite ( } 30) \text {, } \\
\text { calcite (15), dolomite (15), quartz (5), } \\
\text { smectite (5) }\end{array}$ & 17.9 & $301.1 \pm 1.0$ & $360.4 \pm .4$ \\
\hline sme $32 / 1$ & El Entredicho & $\begin{array}{l}\text { muscovite /illite }(40) \text {, quartz }(20) \text {, } \\
\text { chlorite }(10) \text {, albite }(10) \text {, dolomite }(10) \text {, } \\
\text { magnetite (10) }\end{array}$ & 15.5 & $307.6 \pm .9$ & $358.6 \pm .4$ \\
\hline sme $32 / 2<1 \mu \mathrm{m}$ & El Entredicho & $\begin{array}{l}\text { muscovite / illite ( } 40) \text {, chlorite }(10), \\
\text { quartz }(20) \text {, albite (10), dolomite (10), } \\
\text { magnetite (10) }\end{array}$ & 20.1 & $295.2 \pm 1.6$ & $362.3 \pm .8$ \\
\hline sme $32 / 2<0.2 \mu \mathrm{m}$ & El Entredicho & $\begin{array}{l}\text { muscovite /illite }(40) \text {, chlorite }(10) \text {, } \\
\text { quartz }(20) \text {, albite }(10) \text {, dolomite }(10) \text {, } \\
\text { magnetite }(10)\end{array}$ & 18.9 & $297.3 \pm 1.4$ & $360.3 \pm .8$ \\
\hline
\end{tabular}

Mineral assemblages and approximate percentages in parentheses are estimated from XRD spectra. All samples have grain size of $<2 \mu \mathrm{m}$ unless otherwise indicated. El Entredicho samples are from altered volcanic rocks intercalated with mineralized Criadero quartzite (Silurian) and the Las Cuevas sample is from an altered and veined volcanic rock that hosts ore. Illite/chlorite alteration minerals typically make up $5 \%$ of altered rocks and are not present in these high concentrations away from mineralized zones. Error estimates are $2 \sigma$. Full ${ }^{40} \mathrm{Ar} /{ }^{39} \mathrm{Ar}$ data are available as EPSL Online Background Dataset (http://www.elsevier.nl/locate/epsl, mirror site: http://www.elsevier.com/locate epsl).

The quartz vials and surrounding glass manifold used in vacuum encapsulation experiments are transparent. This allows us to shine a defocused beam of visible light from a Coherent INNOVA model $70 \mathrm{Ar}$ ion laser onto the sample. Therefore, the sample's irradiation gas fraction, and all subsequent laser step-heating fractions, can be extracted while the sample remains under high vacuum. Ar isotopes

Table 2

Cr-mica electron microprobe results

\begin{tabular}{lcccccc}
\hline & EE-11 Mica & EE-11 Mica & EE-12 Mica & EE-12 Mica & EE-14 Mica & EE-14 Mica \\
\hline $\mathrm{SiO}_{2}$ & 50.004 & 50.181 & 49.792 & 50.221 & 50.127 & 51.105 \\
$\mathrm{TiO}_{2}$ & 0.025 & 0.057 & 0.087 & 0.072 & 0.360 & 0.024 \\
$\mathrm{Al}_{2} \mathrm{O}_{3}$ & 30.916 & 32.155 & 30.825 & 32.964 & 32.952 & 32.137 \\
$\mathrm{Cr}_{2} \mathrm{O}_{3}$ & 4.122 & 2.203 & 3.564 & 2.077 & 0.213 & 1.489 \\
$\mathrm{FeO}$ & 0.526 & 0.407 & 0.696 & 0.535 & 1.186 & 0.392 \\
$\mathrm{MnO}$ & 0.000 & 0.030 & 0.000 & 0.000 & 0.006 & 0.015 \\
$\mathrm{MgO}$ & 1.206 & 1.070 & 1.245 & 1.186 & 1.817 & 1.389 \\
$\mathrm{CaO}$ & 0.176 & 0.265 & 0.276 & 0.273 & 0.230 & 0.124 \\
$\mathrm{Na}_{2} \mathrm{O}$ & 0.168 & 0.355 & 0.264 & 0.339 & 0.278 & 0.282 \\
$\mathrm{~K}_{2} \mathrm{O}$ & 6.033 & 6.748 & 7.246 & 7.301 & 6.804 & 5.698 \\
$\mathrm{NiO}_{2}$ & 0.034 & 0.000 & 0.000 & 0.074 & 0.140 & 0.111 \\
Total & 93.210 & 93.471 & 93.995 & 95.042 & 94.113 & 92.766 \\
\hline
\end{tabular}

Weight percent of oxides based on 24 oxygen atoms. Analyses were performed with a JEOL JXA-8900 M Electron Probe Micro Analyzer, belonging to the Universidad Complutense de Madrid (UCM), using run time conditions of $15 \mathrm{kV}, 20 \mathrm{nA}$ and a beam diameter of $1 \mu \mathrm{m}$ (approximately). Geostandards are from the Department of Petrology and Geochemistry of the UCM, and from the Smithsonian Institution, Washington. Full ${ }^{40} \mathrm{Ar} /{ }^{39} \mathrm{Ar}$ data are available as EPSL Online Background Dataset (http://www.elsevier.nl/locate/epsl, mirror site: http://www.elsevier.com/locate epsl). 
were measured with either a MAP-215 or VG1200S mass spectrometer and all analyses were performed using an electron multiplier or Daly detector with a gain of approximately $10^{4}$. Mass discrimination was monitored daily by measuring the ${ }^{40} \mathrm{Ar} /{ }^{36} \mathrm{Ar}$ ratio of about $2.5 \times 10^{-9} \mathrm{mlSTP}$ of atmospheric Ar. Fusion system blanks were subtracted from all sample gas fractions and blanks wcre monitorcd frequently, typically every fifth sample fraction. Typical blank values at masses $36-40$ were: $1 \times 10^{-13}, 1.3 \times 10^{-13}$, $5 \times 10^{-14}, 1 \times 10^{-13}$, and $5 \times 10^{-12} \mathrm{mlSTP}$, respectively.

\section{4. ${ }^{40} \mathrm{Ar} /{ }^{39} \mathrm{Ar}$ age of Illite}

A summary of the argon dating results is given in Table 1 and age spectra are shown in Fig. 3. Dong et

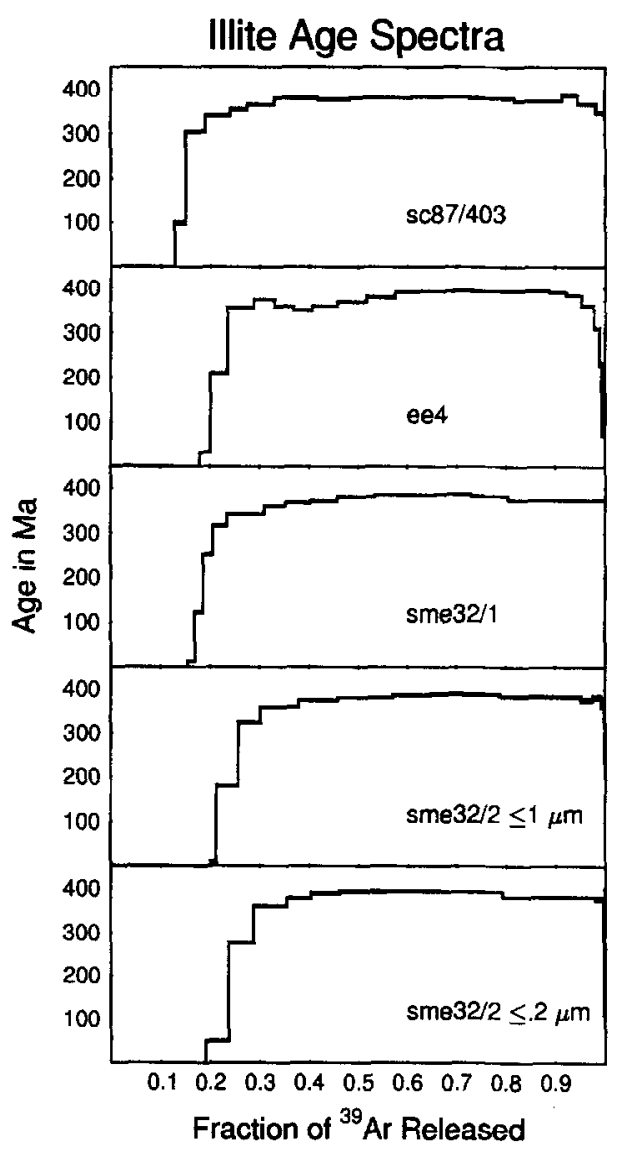

Fig. 3. Age spectra from illite vacuum encapsulation analyses Errors are $\pm 1 \sigma$.

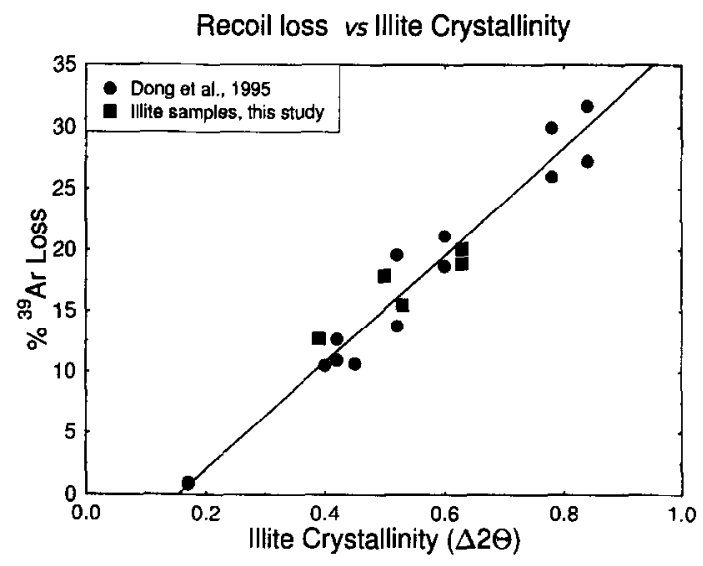

Fig. 4. ${ }^{39} \mathrm{Ar}$ recoil gas lost as a function of illite XRD peak width. Results from this study compared with [5].

al. [5], through a combination of TEM, XRD, and vacuum encapsulation laser ${ }^{40} \mathrm{Ar} /{ }^{39} \mathrm{Ar}$ analyses, showed that the illite structure on the nanometer scale is the dominant control on the quantity of ${ }^{39} \mathrm{Ar}$ lost during irradiation due to recoil. In particular, the degree of ${ }^{39} \mathrm{Ar}$ loss appeared to be inversely proportional to the mean packet thickness, suggesting that ${ }^{39} \mathrm{Ar}$ which does not stop within a protected interlayer site is lost from the sample at room temperature. In the Dong et al. study [5], it was found that the fraction of ${ }^{39} \mathrm{Ar}$ lost due to recoil is a linear function of illite crystallinity as determined by XRD $(\Delta 2 \Theta)$ and our results on illite in this study are fully in accord with the previous finding (Fig. 4).

If the exposed, non-retentive sites in illite also contain $\mathrm{K}$, then an equal proportion of radiogenic ${ }^{40} \mathrm{Ar}$ will have been lost in nature. Thus, the $\mathrm{K}$ in non-retentive sites should not be counted in the total potassium budget if one wants an accurate estimate of the sample's formation age. Unfortunately, the $\mathrm{K}$-Ar method measures the total $\mathrm{K}$ concentration, meaning that $\mathrm{K}-\mathrm{Ar}$ ages, where exchangeable $\mathrm{K}$ has not been previously removed, are at best minimum ages for mineral formation. The total gas ages in this study are completely equivalent to $\mathrm{K}-\mathrm{Ar}$ ages [5] and should therefore be considered as minimum ages for ore emplacement. As can be seen from Table 1, these ages (Total Gas Ages) span about 30 m.y., from 295 to $325 \mathrm{Ma}$. However, the Ar retention ages (Retention Ages, defined as the age derived from $\mathrm{Ar}$ isotopes retained in the illite at room temperature [5]) 
form a very tight cluster of apparent ages which range only from 359 to $363 \mathrm{Ma}$. This is particularly remarkable given the wide range of emplacement ages for the rocks hosting these samples. Dong et al. [5] argued that the Ar retention ages were more reliable than total gas ages, based upon reproducibility and upon agreement with other isotopic dating systems. In this study, the tight clustering of ages near 360 Ma strongly supports the Ar retention age model. Furthermore, the argon retention age model predicts that a sample's total ${ }^{40} \mathrm{Ar} / \mathrm{K}$ ratio should decrease linearly with the fraction of ${ }^{39} \mathrm{Ar}$ lost due to recoil. In Fig. 5, we plot $e^{\lambda t}-1$ (which is proportional to radiogenic $\left.{ }^{40} \mathrm{Ar} / \mathrm{K}\right)$ against the percentage of ${ }^{39} \mathrm{Ar}$ lost due to recoil. The linear trend is exactly as predicted by the Dong et al. [5] model and extrapolating this line back to zero recoil loss yields a limiting age of $360 \mathrm{Ma}$.

The age spectra in Fig. 3 are suggestive of age spectra of minerals which have suffered ${ }^{40} \mathrm{Ar}$ loss [22] and this standard model has been successfully applied to the interpretation of age spectra from high-grade illite samples [5,23]. Awwiller et al. [24] used the high apparent ages in the middle portion of diagenetic grade age spectra to argue for the presence of an older detrital component. However, Dong et al. [5] found that the argon retention age, calculated by adding together all of the retained argon isotopes, was a better measure of diagenetic age than either total gas or apparent 'plateau' ages. It was

\section{Illite Total Gas Age vs Recoil Gas Loss}

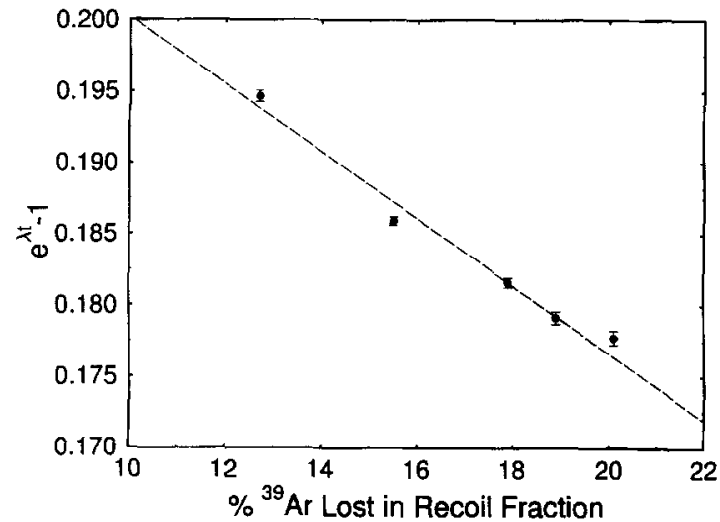

Fig. 5. Illite total gas age as a function of ${ }^{39} \mathrm{Ar}$ lost due to recoil. The argon retention age model [5] predicts $e^{\lambda t}-1$ should be a linear function of ${ }^{39} \mathrm{Ar}$ loss. Errors are $\pm 1 \sigma$ argued that subtle recoil effects were responsible for the high apparent ages in the mid portion of many illite age spectra.

Several important features are apparent in all of the age spectra from samples in this study, as well as in low-grade (i.e. below epizone) illite from Welsh Basin and New York State shales [5]. Immediately after the room temperature recoil fraction, apparent ages are nearly zero, with ages rising to a point above the argon retention age. The overshoot above the retention age is correlated with the degree of ${ }^{39} \mathrm{Ar}$ loss due to recoil, with the highest apparent ages being associated with the highest degree of ${ }^{39} \mathrm{Ar}$ loss and the most poorly crystallized material. Using the standard model of Turner [22], one might ascribe this pattern to ${ }^{40} \mathrm{Ar}$ loss at zero time, with argon blocking at the maximum age indicated by the age spectrum. This is a highly unlikely scenario for low-grade illite, however. If there was significant loss of ${ }^{40} \mathrm{Ar}$ at the present time, little ${ }^{40} \mathrm{Ar}$ should have remained in the mineral after several hundreds of millions of years. Also, one would expect that the most poorly crystallized material would exhibit the youngest 'plateau' ages instead of the highest. Instead of ${ }^{40} \mathrm{Ar}$ loss, the reproducible features seen in Fig. 3 are more likely the result of enhanced ${ }^{39} \mathrm{Ar}$ transport out of the samples during the early stages of laboratory stepheating.

We have constructed a simple model that can explain many of the features seen in low-grade illite age spectra. Consider sample sme $32 / 2$, which experienced about $20 \%$ loss of ${ }^{39} \mathrm{Ar}$ during irradiation. In the model of Dong et al. [5], this sample would have an average packet thickness of five 2:1 structural layers, with a total of 10 interlayer surfaces, 8 interior and 2 exposed (i.e. $20 \%$ of Ar sites are exposed, $80 \%$ are interior interlayer sites). Argon isolopes (both ${ }^{39} \mathrm{Ar}$ and ${ }^{40} \mathrm{Ar}$ ) are retained in the interior interlayer sites and are immediately lost from the exposed sites. However, one would expect that there is some damage to the crystal structure, due to the energetic emplacement of the products of nuclear reactions, and hence there is a high probability of point defects existing near ${ }^{39} \mathrm{Ar}$ atoms. This correlation would not exist for ${ }^{40} \mathrm{Ar}$ atoms, which are produced with much less recoil energy and therefore one would expect that ${ }^{39} \mathrm{Ar}$ atoms that are retained within the crystal structure but which have a defect 


\section{Defect Enhanced Diffusion Age Spectral Models}

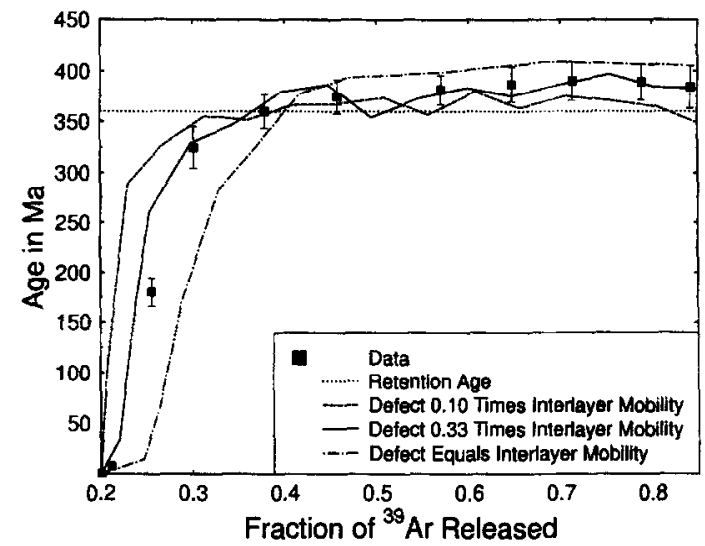

Fig. 6. Results of computer simulations via random walk transport of ${ }^{39} \mathrm{Ar}$ and ${ }^{40} \mathrm{Ar}$ atoms within a hypothetical $1000 \times 1000$ illite interlayer region. See text for details of the model used to generate this result.

nearby would have an enhanced ability to leave the sample over ${ }^{40}$ Ar produced by in situ decay of ${ }^{40} \mathrm{~K}$.

A simple computer model has been constructed to quantitatively test the above arguments. A hypothetical interlayer region is simulated by a 1000 by 1000 point rectangular grid which is randomly populated by $10,000{ }^{40} \mathrm{Ar}$ and $10,000{ }^{39} \mathrm{Ar}$ atoms. The simulated interlayer region is assumed to be within one 2:1 layer of an exposed or defect surface. The Ar atoms are allowed to move one unit distance per time step, either north, south, east, west, up or down. In the case of ${ }^{40} \mathrm{Ar}$ atoms, motion is not allowed in the vertical direction. For $50 \%$ of the ${ }^{39} \mathrm{Ar}$ atoms (i.e. those implanted from outside the crystal), an upward step when the atom is at its point of origin causes a loss of that atom. Otherwise, atoms are lost when they move outside the $1000 \times 1000$ grid space. Two 'vulnerable' interlayers (i.e. those within one 2:1 structural unit of a packet surface) are assumed to exhibit this kind of degassing, while the two interior interlayers have both ${ }^{40} \mathrm{Ar}$ and ${ }^{39} \mathrm{Ar}$ exiting only via the crystal edges. One can see that, for well crystallized illites which have mean packet thickness of hundreds of layers [5], the effect of defect-enhanced transport of ${ }^{39} \mathrm{Ar}$ is relatively unimportant, as only a small percentage of atoms can communicate directly with the packet's exterior. Synthetic age spectra are constructed by scaling the released ${ }^{40} \mathrm{Ar} /{ }^{39} \mathrm{Ar}$ ratios to yield a retention age of $360 \mathrm{Ma}$.
The results of this simulation are shown in Fig. 6. Roughly 350,000 time steps were required to achieve $85 \%{ }^{39}$ Ar degassing. Three runs were performed: one where the probability of defect transport equalled that of motion along the interlayer zone; one with $33 \%$ probability of transport through the defect; and one with $10 \%$ probability of defect transport. When compared with the data from sme $32 / 2$, one can see that the computer simulations can mimic the laboratory data quite well, particularly the $33 \%$ probability model. The error bars shown in Fig. 6 represent the expected scatter caused by using only 20,000 atoms to recreate the age spectrum and they are comparable to the fluctuations seen in the computer simulations. The success of this simple model argues that the high 'plateau' ages seen in low-grade illite samples may be a recoil artifact and should not be interpreted as representing the original blocking age of the mineral. Therefore, we regard the argon retention age of $360 \mathrm{Ma}$ as representing the best estimate for the blocking age for these samples.

Table 3

Cr-mica dating results

\begin{tabular}{lccll}
\hline $\begin{array}{l}\text { Sample } \\
\text { number }\end{array}$ & Run & $\begin{array}{l}{ }^{39} \text { Ar in } \\
\text { recoil } \\
\text { fraction } \\
(\%)\end{array}$ & $\begin{array}{l}\text { Total gas age } \\
(\mathrm{Ma})\end{array}$ & $\begin{array}{l}\text { Retention age } \\
(\mathrm{Ma})\end{array}$ \\
\hline EE11 & $\mathrm{a}$ & 9.0 & $343.5 \pm 1.7$ & $374.3 \pm 1.0$ \\
EE11 & $\mathrm{b}$ & 12.9 & $345.8 \pm 1.0$ & $391.5 \pm 0.4$ \\
EE11 & $\mathrm{c}$ & & & $393.1 \pm 2.8$ \\
FE11 & d & & & $407.4 \pm 2.6$ \\
EE11 & $\mathrm{e}$ & & & $426.9 \pm 2.8$ \\
EE12 & $\mathrm{a}$ & 12.9 & $331.2 \pm 2.4$ & $375.7 \pm 2.0$ \\
EE12 & $\mathrm{b}$ & & & $364.3 \pm 3.0$ \\
EE12 & $\mathrm{c}$ & & & $383.8 \pm 3.2$ \\
EE12 & $\mathrm{d}$ & & & $396.2 \pm 3.6$ \\
EE14 & $\mathrm{a}$ & & & $394.9 \pm 7.2$ \\
EE14 & $\mathrm{b}$ & & & $401.5 \pm 3.2$ \\
EE14 & $\mathrm{c}$ & & & $398.8 \pm 4.4$ \\
\hline
\end{tabular}

All samples consisted of fine-grained chromium-rich mica hosted by ankerite and siderite. Semiquantitative XRD data for the three samples (whole rock) are very similar: 5-10\% quartz, 20-30\% phyllosilicates, $30-50 \%$ ankerite, and $20-40 \%$ siderite. Runs EE11 (a) and (b) and run EE12 (a) were vacuum encapsulated and ${ }^{39} \mathrm{Ar}$ lost due to recoil could be collected. In all other cases, the samples were irradiated in vacuo, but recoil gas was not collected. Therefore argon retention ages are only available for three samples. A quartz capsule with a sample of EE14 was lost due to breakage in the laboratory. Error estimates are $2 \sigma$. 


\section{5. ${ }^{40} \mathrm{Ar} /{ }^{39} \mathrm{Ar}$ age of $\mathrm{Cr}$-mica}

Fig. 7 shows the age spectra from the twelve analyses of carbonate-hosted Cr-mica samples EE-11, 12 and 14. In general, these age spectra display similar features to those seen in Fig. 3 and in [5]. From Fig. 7a,b,f and Table 3 it can be seen that the recoil loss of ${ }^{39} \mathrm{Ar}$ is significantly less than was found for the Almadén illite samples, suggesting that the $\mathrm{Cr}$-mica has a greater mean packet thickness. Unlike the illite samples, the individual clumps of Cr-mica have a broad range of ages, from 364 to $427 \mathrm{Ma}$. This variability exists even within a single hand specimen (Table 3).

Some of the age spectra in Fig. 7 show unusual deviations from the patterns seen in Fig. 3 and [5], but the Cr-mica samples had a significant Ca-rich carbonate component, which may explain some of these features. With a Ca-rich mineral intimately intergrown with the $\mathrm{Cr}$-mica, there is the potential

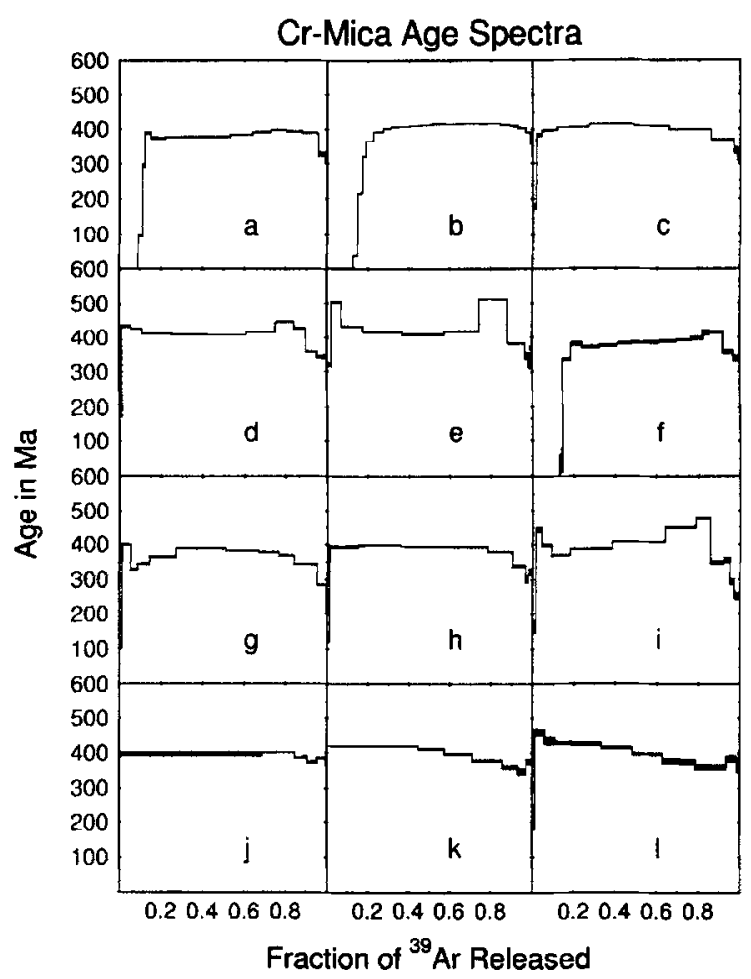

Fig. 7. Cr-mica age spectra. (a)-(e) EE-11 runs a-e; (f)-(i) EE-12 runs a-d; (j)-(l) EE-14 runs a-c. (a), (b) and (f) were vacuum encapsulated. Errors are $\pm 1 \sigma$. for ${ }^{39} \mathrm{Ar}$ and ${ }^{37} \mathrm{Ar}$ exchange between minerals due to recoil, which could cause disturbances in the age spectra.

\section{Significance of ${ }^{40} \mathrm{Ar} /{ }^{39} \mathrm{Ar}$ age measurements at Almadén}

The 359-363 Ma ages obtained in this study for illite record an event that is about 80 million years younger than the age of the Criadero quartzite [14], which hosts stratiform mercury mineralization at $\mathrm{Al}$ madén and is at least 20 myr younger than the youngest (Devonian age) rocks that host vein mineralization. Folger et al. [25] found that it is difficult to reset detrital illite during gold mineralization, which took place at temperatures similar to those of the Almadén mineralization, which suggests that significant heating and/or recrystallization is necessary to reset the argon clock in illites. Similarly, Dong et al. ([5] and unpubl. data) have found that diagenetic illite in sediments of the Welsh Basin needed at least epizone grade of metamorphism to cause complete degassing. The illite crystallinity of the Almadén samples, based on XRD data and ${ }^{39} \mathrm{Ar}$ recoil loss [5], suggests that they are of diagenetic grade, which is too low a grade of metamorphism to reset the samples in a sedimentary basin. If later metamorphism had reset the argon isotopes in these samples, we would expect to observe a higher metamorphic grade. It is likely, therefore, that the $360 \mathrm{Ma}$ age recorded in these illites represents the time of their formation as alteration minerals around the mercury ore, and therefore the time that the associated mercury ore was emplaced. These ages, therefore, confirm suggestions that the vein-hosted mineralization at Las Cuevas was formed during Hercynian metamorphism or magmatism. Whether the mercury was newly introduced at this time, or was remobilized from mercury that was deposited by an earlier event depends on interpretation of the ages obtained for the Cr-mica. See Fig. 8 for a histogram of the argon retention ages found in this study.

The 427-364 Ma ages obtained in this study for Cr-mica cover a much wider range than the illite ages and probably represent resetting of an older age at or beyond the oldest age we have obtained from this material. The oldest age $(427 \mathrm{Ma})$ is similar to 
the age of the early to middle Silurian sedimentary and volcanic rocks that host mineralization at El Entredicho and Almadén, and it is most simply interpreted as the approximate age of formation of the early, ore-related alteration assemblage. The younger ages fall between this age and the age of the illite and are interpreted as representing incompletely reset $\mathrm{Cr}$-mica ages.

The variability of argon retention ages cannot be due to variations in thermal history between the samples, as there are significant age differences within a single hand specimen. In hindsight, it is fortunate that mineral separation was not attempted, as this would have homogenized the samples and much of this variability would have been eradicated. We suspect that local variations in grain size, chemistry and fluid flow during the later metamorphic event has caused this fine-scale heterogeneity. We note that $\mathrm{Cr}$ content in the micas, particularly in sample EE-14, are highly variable (Table 2 ) which may be a chemical manifestation of a heterogeneous response to the later metamorphic event.

The ages obtained here indicate that mercury mineralization in the Almadén region took place in at least two episodes; one in early Silurian time and another ending in early Carboniferous time. This suggests, in turn, that mercury was deposited both by the alkali basalt volcanic rocks and by later Hercynian metamorphism or magmatism. The early event remains poorly constrained, although it probably took place shortly after deposition of the ore-hosting Lower Silurian Criadero quartzite. Heat and hydrothermal solutions that formed this mineralization were probably related to volcanism that took place at this time [15]. The Late Devonian-Early Carboniferous 359-363 Ma ages coincide with early stages of Hercynian deformation and metamorphism, as well as early plutonic activity throughout the central Iberian peninsula [26]. The possibility of a Late Devonian metamorphic fluid event in the Almadén area is supported further by data from other studies. Nägler et al. [27] report a Rb-Sr errorchron age(?) of $335 \pm 15 \mathrm{Ma}$ for micas in Ordovician sediments around Almadén, which they suggest is related to deformation and metamorphism. More importantly, Parès and Van der Voo [28] have pointed out from their data and that of Perroud et al. [29], that paleomagnetic poles for Ordovician and Silurian rocks in

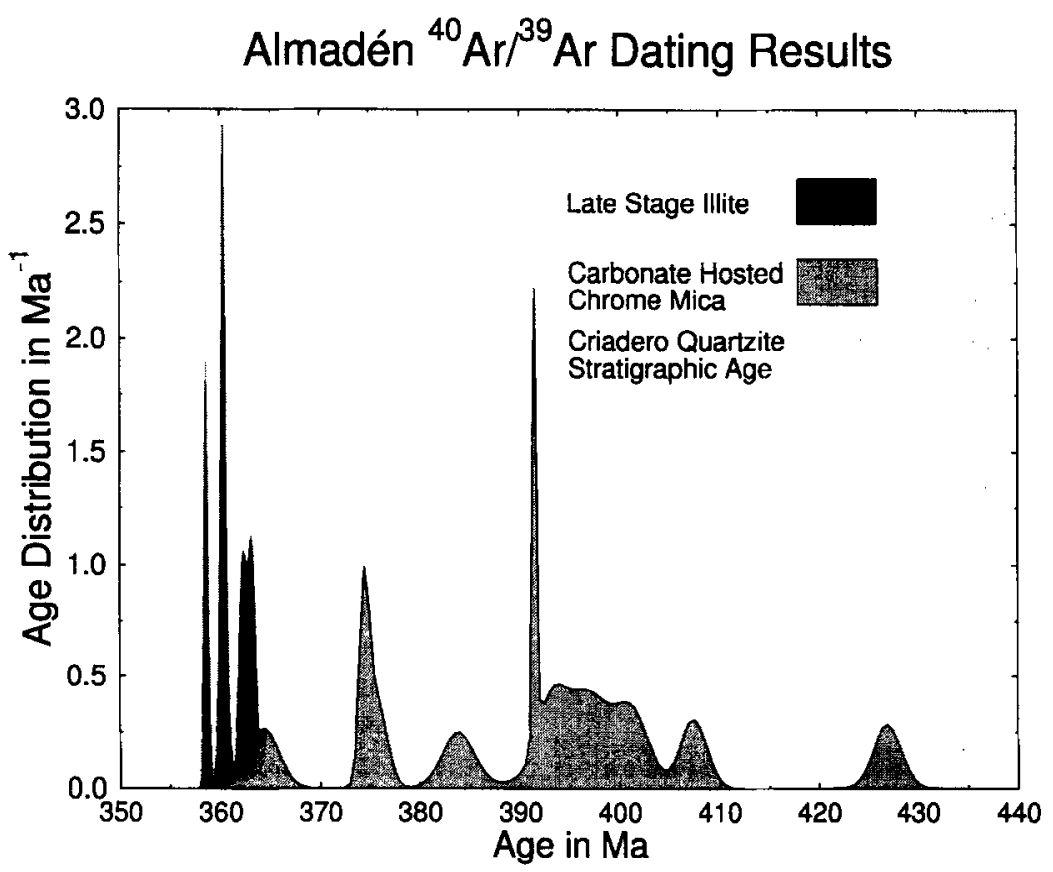

Fig. 8. Histogram of all argon retention ages from this study. Ages are plotted as their Gaussian age distribution based on their estimated analytical precision. 
the Almadén area record an overprint of possible Devonian age, roughly the same age as the 359-363 Ma age range reported here. Parès and Van der Voo [28] also recognized a second paleomagnetic overprint in the Almadén area, which they ascribed to Early Carboniferous. This event possibly correlates with hydrothermal activity related to widespread intermediate to granitic plutonic activity that took place in the area, including the Fontanosas granite $(312 \pm 7 \mathrm{Ma})$, which is just east of Almadén and the Pedroches batholith to the south of Almadén [26,30]. Although our total gas ages of 321-295 Ma correspond roughly to that age range, it is likely that this is a coincidence rather than a geologically meaningful correlation. Still later thermal events that were probably related to one or more younger hydrothermal systems are represented by $\mathrm{K}-\mathrm{Ar}$ ages of 119-285 Ma for clay concentrates from the Pedroches batholith [31].

\section{Conclusion}

The ${ }^{40} \mathrm{Ar}-{ }^{39} \mathrm{Ar}$ ages obtained here for $\mathrm{Cr}$-mica and fine-grained muscovite/illite from altered rocks in the Almadén district confirm geologic interpretations that mercury mincralization was closely associated with alkalic volcanism but indicate that some mercury was remobilized during Hercynian metamorphism. More age measurements are needed before we can be certain about the relative proportions of mercury deposited by alkalic volcanism and Hercynian magmatism or metamorphism, although several lines of evidence suggest that most mercury was deposited by alkalic volcanism, with the Hercynian event serving largely to remobilize it. Most important among these are the strong association between ore and frailesca breccias and the fact that Hercynian age pyrophyllite-kaolinite-illite alteration is directly associated only with obviously remobilized ore. If these interpretations are correct, we must conclude that alkali basalt volcanism can form important mercury accumulations. It follows that exhalation of this mercury in submarine hot springs associated with these volcanic rocks could be the source of mercury observed in some shales, both at Almadén and in other parts of the world $[10,32,33]$.

\section{Acknowledgements}

We are grateful to $R$. Oyarzun (University of Madrid), who participated in the initial planning of the field work and in sample selection, to Juliana Parras (University Castilla-La Mancha), who helped with mineral separations, and to A. Hernández, who provided access to the Almadén deposits and guidance in the field. We wish to acknowledge the assistance of the Phoenix-Ford Memorial Project for performing the neutron irradiation. Electron microprobe assistance in Madrid was provided by Dr. José González del Tánago and Alfredo Fernández Larios. Laboratory assistance at Michigan was also provided by Marcus Johnson, E.H.P. Van Hees and Angela Briethaupt. This project is funded by a grant from the National Science Foundation to $\mathrm{CMH}$ and SEK (EAR-9526673), and from the Universidad de Castilla-La Mancha "Grupos Precompetitivos" program to PLH. [CL]

\section{References}

[1] E. Ortega. A. Hernández, The mercury deposits of the Almadén syncline Spain, Chron. Mines Rech. Minière 506 (1992) 3-11.

[2] W.F. Fitzgerald, Atmospheric and oceanic cycling of mercury, in: J.P. Riley, R. Chester (Eds.), Chemical Oceanography, Vol. 10, 1989, pp. 151-186.

[3] J.O. Nriagu, A global assessment of natural sources of atmospheric trace metals, Nature 338 (1989) 47-49.

[4] P.E. Smith, N.M. Evensen. D. York, First successful ${ }^{40} \mathrm{Ar}-$ ${ }^{39} \mathrm{Ar}$ dating of glauconites; argon recoil in single grains of cryptocrystalline material, Geology 21 (1993) 41-44.

[5] 11. Dong, C.M. Hall, J.R. Peacor, A.N. Halliday, Mcchanisms of argon retention in clays revealed by laser ${ }^{40} \mathrm{Ar} /{ }^{34} \mathrm{Ar}$ dating, Science 267 (1995) 355-359.

[6] Higueras, P., Munhá, J., Geochemical constraints on the petrogenesis of mafic magmas in the Almadén mercury mining district, Terra Abstr. (1993) 5.

[7] Higueras, P., Procesos petrogenéticos y de alteración de las rocas magmáticas asociadas a las mineralizaciones de mercurio del distrito de Almadén. Ph.D. Thesis, Univ. Granada, 1994.

[8] B. Sáinz de Baranda, H.R. Lunar, El volcanismo alcalino pre-Hercinico del sinclinal de Almadén. Estud. Geol. 45 (1989) 337-348.

[9] P. Higueras, D. Morata, J. Munhá, Metamorfismo de bajo grado en facies prehnita-pumpellyita en las metabasitas del sinclinal de Almadén. Bol. Soc. Esp. Mineral. 18 (1995) $111-125$. 
[10] F. Saupé, La géologie du gisement de mercure d'Almadén (Province de Ciudad Real, Espagne), Sci. Terre 29 (1973) 342.

[11] R. Wagner, Upper Stephanian stratigraphy and paleontology of the Puertollano Bassin, Ciudad Real, Spain, An. Fac. Cienc. Porto 64 (1985) 171-193.

[12] F. Saupé, Geuluzy of the Almitén mercury deposit, Province of Ciudad Real, Spain, Econ. Geol. 85 (1990) 482-510.

[13] J. Borrero, P. Higueras, Nuevos conocimientos sobre la geología y metalogénesis de los yacimientos de mercurio de Almadén (Ciudad Real), Bol. Geol. Min. 101 (6) (1990) 48-67.

[14] A. García Palacios, J.C. Gutierrez-Marco, P. Herranz, Edad y correlación de la "Cuarcita de Criadero" y otras unidades cuarcíticas del límite Ordovícico-Silúrico en la Zuna Centroibérica meridional (España y Portugal), Geogaceta 20 (1) (1996) 19-22.

[15] J.J. Rytuba, A.M. Hernandez, R.O. Rye, J.A. Dean, A. Arribas Sr., Genesis of Almadén-type mercury deposits, Almadén, Spain, in: Abstr. 28th Int. Geol. Congr., Vol. 2, Washington, 1989, p. 741.

[16] M. Jébrak, A. Hernández, Tectonic deposition of mercury in the Almadén district, Las Cuevas Deposit, Spain, Miner. Deposita 30 (1995) 413-423.

[17] F. Saupé, M. Arnold, Sulphur isotope geochemistry of the ores and country rocks at the Almadén mercury deposit, Ciudad Real, Spain, Geochim. Cosmochim. Acta 56 (1992) $3765-3780$.

[18] H. de Boorder, A.B. Westerhoff, Tectonic control of early to middle Paleozoic volcanism and related mercury and antimony mineralization in southern central Iberia, Econ. Geol. 89 (1994) 656-661.

[19] Higueras, P., Alteration of basic igneous rocks from the Almadén mining district, in: P. Fenoll, J. Torres, F. Gervilla (Eds.), Current Research in Geology Applied to Ore Deposits, Univ. Granada, 1993, pp. 131-134.

[20] P. Higueras, J. Parras, C. Sanchez, Procesos de alteración asociados a la removilización hidrotermal de cinabrio en el yacimiento de "Las Cuevas" (Almadén, Ciudad Real), Bol. Soc. Esp. Mireral. 18 (1995) 191-200.

[21] S.D. Samson, E.C. Alexander, Calibration of the interlaboratory ${ }^{40} \mathrm{Ar}-{ }^{39} \mathrm{Ar}$ dating standard, Mmbb-1, Chem. Geol. 66 (1987) 27-34.

[22] Turner, G., Thermal histories of meteorites by the ${ }^{39} \mathrm{Ar}-{ }^{40} \mathrm{Ar}$ method, in: P.M. Millman (Ed.), Meteorite Research, Kluwer, Dordrecht, 1969, pp. 407-417.

[23] C.J. Bray, E.T.C. Spooner, C.M. Hall, D. York, T.M. Bills,
H.W. Krueger, Laser probe ${ }^{40} \mathrm{Ar} /{ }^{39} \mathrm{Ar}$ and conventional $\mathbf{K}$-Ar dating of illites associated with the McClean unconformity-related uranium deposits, North Saskatchewan, Canada, Can. J. Earth Sci. 24 (1987) 10-23.

[24] D.N. Awwiller, R. Burgess, L.K. Ayliffe, G. Turner, ${ }^{40} \mathrm{Ar} /{ }^{39} \mathrm{Ar}$ systematics in a diagenetic-to contact metamorphic-grade clay mineral suite, Northern North Sea, in: 8th Int. Conf. on Geochronology, Cosmochronology and Isotope Geology, U.S. Geol. Surv. Circ. 1107 (1994) 15.

[25] H.W. Folger, L.W. Snee, H.H. Mehnert, A.H. Hofstra, A.R. Dahl, Significance of $\mathrm{K}-\mathrm{Ar}$ and ${ }^{40} \mathrm{Ar} /{ }^{39} \mathrm{Ar}$ dates from mica in Carlin-type gold deposits: evidence from the Jerritt Canyon district, Nevada, in: Geology and Ore Deposits of the American Cordillera, Reno/Sparks, Nevada, Program with Abstracts, 1995, A31,

[26] M. Serrano Pinto, C. Casquet, E. Ibarrola, L.G. Corretegé, M. Portugal Ferreira, Sintese geocronologica do granitoides do Maciço Hesperico, Estud. Geol. 50 (1994) 69-86.

[27] T.F. Nägler, H.-J. Schäfer, D. Gebauer, A Sm-Nd isochron on pelites $1 \mathrm{Ga}$ in excess of their depositional age and its possible significance, Geochim. Cosmochim. Acta 56 (1992) $789-795$

[28] J. Parès, R. Van der Voo, Paleozoic paleomagnetism of Almadén, Spain: A cautionary note, J. Geophys. Res. 97 (1992) 9353-9356.

[29] H. Perroud, F. Calza, D. Khattach, Paleomagnetism of the Silurian volcanism at Almadén, Southern Spain, J. Geophys. Res. 96 (1991) 1949-1962.

[30] F. Leutwein, F. Saupé, J. Sonet, E. Bouyx, Première mesure géochronologique en Sierra Morena: La granodiorite de Fontanosas (Province de Ciudad Real, Espagne), Geol. Mijnb. 49 (1970) 297-304.

[31] A.N. Halliday, J.G. Mitchel, K-Ar ages of clay-size concentrates from the mineralization of the Pedroches Batholith, Spain, and evidence for Mesozoic hydrothermal activity associated with the break up of Pangaea, Earth Planet. Sci. Lett. 68 (1984) 229-239.

[32] C.E. Peabody, M.T. Einaudi, Origin of petroleum and mercury in the Culver-Baer cinnabar deposit. Mayacmas district, Califomia, Econ. Geol. 87 (1992) 1078-1104.

[33] E.M. Cameron, I.R. Jonasson, Mercury in Precambrian shales of the Canadian Shield. Geochim. Cosmochim. Acta 36 (1972) 985-1005.

[34] Hernandez Sobrino, A., Estructura y génesis de los yacimientos de mercurio de la zona de Almadén, Ph.D. Thesis, Univ. Salamanca, 1984, 317 pp. 